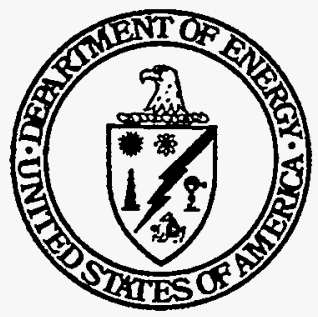

\title{
General Requirements for RCRA Regulated Hazardous Waste Tanks
}

\section{Background:}

The Resource Conservation and Recovery Act (RCRA), as amended, requires that tanks used for the storage or treatment of hazardous waste (HazW) be permitted; and comply with the requirements conlained within the Code of Federal Regulations (CFR) Title 40 in Subpart $\mathrm{J}$ of Part 264/265, unless those tanks have been exempled.

Subpart $I$ specifies requirements for the design, construction, installation, operation, inspection, maintenance, repair, release response, and closure of HazW tanks. Also, the regulations make a distinction between "new" and "existing" tanks. Existing HazW tanks are those for which constriction commenced on or before July 14,1986 . New HazW tanks are those for which constuction commenced after that date. Existing tanks that are retumed to service after being repaired are also considered "new" tanks. The requirements for the two tank classifications are substantively the same, except that existing tanks are subject to integrity testing requirements, and new tanks require a seconday containment system, which needs to be installed prior to putting the tank into service, Additionally, continued operation of existing tanks will require installation of a secondary containment system in accordance with a schedule detemined by the Environmental Protection Agency (EPA).

Effective December 6, 1995, standards for controlling volatile organic air emissions will apply to non-exempt HazW tanks. HazW tanks will have to be equipped with a cover or floating toof, or be designed to operate as a closed system, to be in compliance with the air emission control requirements. These standards, which have been codified as 40 CFR Part 264/265 Subpart CC, include waste determination, monitoning, inspection, recordkeeping, and reporting procedures that are applicable to tanks that control volatile organic air emissions through the use of covers.

This Information Brief will describe those tanks that are subject to the subpart $\mathrm{J}$ requirements, and will also discuss secondary containment, inspection, restrictions on waste storage, release response, and closure requirements associated with regulated HazW tanks.

Statutes: . Resource Conservation and Recovery Act (RCRA), as amended.

Regulations: 40 CFR 262, Standards Applicable to Generators of Hazandous Waste

40 CFR 264/265, Subpart J - Tank Systems (pemitted facilitiesintenim status facilites)

40 CFR. 264/265, Subpart CC - Organic Air Emission Standards

References: 1. Technical Resource Document for the Storage and Treatment of Hazardous Waste in Tank Systems, U.S. Environmertal Protection Agency, 1986

2. Flammable and Combustible Liquids Code, National Fire Protection Association, 1984

3. "Organic Air Emission Standards; Final Rules Issued," U.S. Department of Energy, Office of Environmental Policy \& Assistance, RCRACERCLA Division;(EH-413), Regulatory Bulletin, August 1995.

4. U.S. Environmental Protection Agency 1995, Notice of Proposed Effective Date for Volatile Organic Compound Emissions final Rule. Federal Register. 60(83): 26828. 


\section{Which hazardous waste tanks are covered under these regulations?}

All tank systems storing or treating liquid HazW, nonliquid HazW (such as solid hazardous wastes, residues, dried sludge, etc.), and/or gaseous HazW are covered and need to comply with the regulations in Subpart J, unless they qualify for a variance or are otherwise exempted.

\section{What types of tanks are completely exempted from Subpart J?}

There are three types of tank systems that are completely exempted from regulations contained in Subpart J. These are:

Systems that are part of a totally enclosed treatment unit. Such a treatment unit would be directly connected to an industrial process, and would be constructed and operated in a manner that prevents the release of HazW into the environment. [40 CFR 264/265.1(g)(5)]

Systems that are part of a wastewater treatment unit at a facility regulated under the Clean Water Act Sections 402 or $307(\mathrm{~b})$, and that receive, generate, treat, or store HazW. [40 CFR 264/265.1(g)(6)]

Systems that are part of an elementary neutralizing unit (i.e., a unit used for neutralizing corrosive $\mathrm{HazW}$ ). [40 CFR 264/265.1(g)(6)]

\section{Are any HazW tanks exempted from only part of the Subpart $\mathrm{J}$ regulations?}

There are three types of tank systems that are exempted from the secondary containment regulations. These are:

Those that are located indoors, that have an impervious floor, and that contain no free liquids as determined by EPA's Paint Filter Liquids Test. [40 CFR 264.190(a)];

Tank systems, including sumps (defined as any pit or reservoir that meets the definition of a tank and those troughs/trenches connected to it) that serve as a part of a secondary containment system to collect or contain releases of HazW [40 CFR 264.190(b)]; and

$\square$ Tank systems that have received a variance from the secondary containment requirements. [40 CFR 264.190(c)]

Secondary containment may be in the form of an external liner, vault, or double-walled tank, or an equivalent device approved by the EPA Regional Administrator. To obtain approval for an alternative secondary containment device, the owner/operator must demonstrate either that the device is equally protective of groundwater or surface water, or that if HazW is released to these media it would pose no threat to human health or the environment. [40 CFR 264.193(d)]

Tanks with secondary containment are not subject to the integrity testing requirements. [40 CFR 264.191(a)]

\section{How are "existing" HazW tanks regulated differently from "new" HazW tanks?}

For purposes of Subpart J, an existing tank is any tank system that is in operation or for which installation has commenced prior to July 14, 1986. [40 CFR 260.10] A "new" tank system is any system for which installation commenced after that date. This includes "used" tanks that are being reinstalled as replacement tanks.

A new tank cannot be placed into service without secondary containment. Existing tanks must eventually receive secondary containment according to a schedule determined by EPA. This schedule, which was developed by EPA to lessen the burden of compliance on the regulated community, provides that:

All existing tank systems used to store or treat EPA "Flisted" HazW numbers F020, F021, F023, F026, and F027 must have received secondary containment not later than January 12, 1989 [40 CFR 264/ 265.193(a)(1)];

For existing tanks systems of known and documented age, secondary containment must have been provided by January 12,1989 , or when the tank system has reached 15 years of age, if that date is later [ 40 CFR 264/265.193(a)(2)];

For existing tank systems for which the age cannot be documented, secondary containment must be provided by January 12,1995; but if the age of the facility is greater than 7 years, secondary containment must be provided by the time the facility reaches 15 years of age, whichever comes later. $[40$ CFR 264/265.193(a)(3)]

Existing tanks are also subject to integrity testing requirements if they do not have secondary containment. Integrity testing involves examining the tank system and equipment to determine if it has sufficient strength and compatibility with the HazW being stored to ensure that it will not collapse, rupture, or fail. An integrity test would normally consider the tank's design standards, existing corrosion protection measures, the tank's age, and the characteristics of the HazW being stored. [40 CFR 264.191(b)]

\section{Does the size of the tank affect its regulation as a HazW tank?}

No. EPA did not establish any exemption based upon the size of the tank. However, tanks that contain small quantities $(100-1,000 \mathrm{~kg})$ of HazW are not regulated by the full spectrum of the HazW tank regulations. They are subject to the Subpart $\mathrm{J}$ inspection requirements and applicable restrictions on holding ignitable, reactive, or incompatible wastes. They are also subject to emergency response procedures and closure/post-closure requirements. [40 CFR 265.201]

These small quantity wastes may not be stored for more than 180 days (or 270 days if destined for shipment over a 
distance greater than 200 miles), and no more than $6,000 \mathrm{~kg}$ of waste may be accumulated at one time without being subject to the full spectrum of HazW tank regulations. [40 CFR 265.201(a)]

\section{Do hazardous waste tanks have to be inspected regularly?}

Tanks must be inspected daily to determine the presence of corrosion, deterioration of liners, cracking of welds and joints, cracking in concrete tanks and secondary containment systems, structural fatigue, or leaks. This involves inspection of overfill/spill control equipment, inspection of all aboveground portions of the system for corrosion or leaks, and inspection of areas surrounding the tank for signs of erosion or release of hazardous waste. Also, data from leak detection equipment must be evaluated daily and kept in the facility's operating log. [40 CFR 264/265.195]

\section{How does the presence of radioactive waste affect the regulations of HazW tanks under 40 CFR Subpart J?}

Tanks containing radioactive waste mixed with hazardous waste (RMW) are to be regulated in the same manner as a HazW tank under 40 CFR Subpart J. Pursuant to the byproduct material interpretative rule (52 FR 15937; May 1, 1987) and the RMW clarification notice (53 FR 37045; September 23, 1988), the hazardous component of a RMW must be managed under RCRA to the extent that such management is not inconsistent with the provisions of the Atomic Energy Act (AEA) with which DOE must also comply for the radioactive component of the mixed waste.

The radioactive and HazW components of RMW are often not easily separated. Managers of RMW tanks must coordinate with EPA and/or authorized states to determine alternative or modified approaches to compliance with appropriate Subpart J requirements when necessary to protect workers from increased radiation exposure.

\section{Are there restrictions on the types of HazW that can be stored in tanks?}

Ignitable or reactive wastes must not be placed in HazW tank systems unless, as required by 40 CFR 264/265.198:

The HazW is treated or mixed before or immediately after placement in the tank system so that the resulting material no longer meets the definition of ignitable or reactive waste under $40 \mathrm{CFR} 261.21$ or 261.23 , and the requirements of 40 CFR 264/265.17(b) (see below) are met; or

D The HazW is stored or treated so that it is protected from any material or conditions that may cause the $\mathrm{HazW}$ to ignite or react; or

The tank system is used solely for emergencies.

Under 40 CFR 264/265.17(b), the owner or operator of a facility that treats or stores ignitable, reactive, or incompatible HazW must take precautions to prevent reactions that:

Generate extreme heat, pressure, fire, explosions, and/or violent reactions, or produce uncontrolled toxic mists, fumes, dusts, or uncontrolled flammable fumes or gases, in quantities sufficient to threaten human health or the environment;

Damage the structural integrity of the device or facility; or

Produces other sources of harm to human health or the environment.

The owner/operator of a facility where ignitable or reactive HazW is stored or treated in a tank needs to maintain protective distances between the waste management area and any public ways, streets, alleys, or adjoining property lines that can be built upon. (See Reference 2.)

It also needs to be determined that the HazW is compatible with other $\mathrm{HazW}$ with which it might be stored or treated, and with the tank itself. Incompatibility of hazardous wastes may result in explosions or fires. (See Reference 2.)

\section{What procedures are necessary to close a HazW tank?}

To close a HazW tank, the owner/operator must remove or decontaminate all waste residues, contaminated containment system components, contaminated soils, and structures and equipment contaminated with waste, and manage them as hazardous waste, unless the residue, component, soil, or equipment no longer exhibits the characteristics of a hazardous waste as described in $40 \mathrm{CFR}$ 261.3(d) (Solid wastes that are not hazardous wastes).

Closure of a HazW tank in this manner is often referred to as "clean closure."

HazW tanks that lack secondary containment and that were not granted a variance from secondary containment must prepare a plan for closing in the manner described above, and a contingent plan for closing in the same manner as a landfill (40 CFR 264/265.310), including a post-closure plan for the same. [40 CFR 264.197(c)]

\section{How is the tank to be closed if clean closure is not possible?}

If clean closure is not possible, the HazW tank must close in the same manner as a HazW landfill. These requirements, which are found in $40 \mathrm{CFR} 264 / 265.310$, are more stringent as they require post-closure care. It is EPA's intent under the post-closure care requirements that the HazW tank, associated structures, and any contaminated soils will not pollute the environment or pose a health hazard to the local community. [40 CFR 264/265.197(b)] 
What requirements apply if a tank contains a newly designated HazW?

If the tank contains a waste that EPA has recently designated as hazardous, then all applicable regulations from Subpart J of Subtitle C apply to that tank. [40 CFR 264/265.191(c)] If the tank contains a radioactive mixed waste, and the hazardous waste portion is a newlydesignated HazW, that tank also is regulated under Subpart J of Subtitle C.

\section{What release response requirements apply?}

In the event that a release of $\mathrm{HazW}$ occurs from a tank system, the Regional Administrator of the EPA must be notified of the release. However, if the spill was less than one pound and immediately cleaned up, no notification to the Regional Administrator is required. If notification of the spill is provided to the National Response Center (NRC), notification to the Regional Administrator is not required. [40 CFR 264/265.196(d)]

Within 30 days of release detection, a report must be submitted to the EPA Regional Administrator describing the likely route of release migration; characteristics of the surrounding soil; proximity of release to ground water, surface water, or drinking water, and the response action planned. Sampling data should also be provided as soon as they are available. [40 CFR 264/265.196(d)]

\section{Are HazW tanks subject to organic air emission control standards?}

Yes. Unless the tank has been deferred, any tanks receiving waste after December 6, 1995, must comply with the standards specified in 40 CFR 264/265.1080 through 1091 [Subpart CC - Organic Air Emission Standards for Tanks, Surface Impoundments, and Containers]. The owner/operator is required to determine the volatile organic concentration of hazardous waste that has been placed in a tank. If a HazW tank contains waste that emits volatile organics, it must be equipped with a cover or roof or be designed to operate as a closed system.

\section{Are Subpart CC requirements applicable to process vents or control devices associated with HazW tanks?}

Where closed-vent systems are used to route volatile organics from HazW tanks to a carbon absorption control device (40 CFR 264/265.1031), the device must be operated such that following initial startup, spent activated carbon is replaced with fresh carbon on a regular basis in accordance with 40 CFR $264 / 265.1033(\mathrm{~g})$ or $264 / 265.1033(\mathrm{~h})$. Furthermore, the owner/operator must document that all carbon removed from the control device is managed by either being: 1) regenerated or reactivated in a thermal treatment unit that is permitted under 40 CFR 264 Subpart $\mathrm{X}$ (Miscellaneous Units; 2 ) incinerated by a.process that is permitted under 40 CFR 264/265 Subpart O (Incinerators); or 3) burned in a boiler or industrial furnace that is permitted under 40 CFR 266 Subpart $H$ (Hazardous Wastes
Burned in Boilers and Industrial Furnaces). [40 CFR 264.1033(m)]

\section{Which units have received a deferral from the organic air emission control standards?}

These standards were temporarily deferred for units containing RMW, or units used in RCRA or CERCLA site remediation activities. [40 CFR 264/265.1080(b)(5) and (6)]

Are there any additional exclusions from all or part of the organic air emission regulations?

Yes. Tanks that contain HazW that: 1) has a volatile organic concentration at the point of waste origin that is less than $100 \mathrm{ppm}$ by weight or for which the organic content of the waste has been reduced by an organic destruction or removal process that achieves any of the levels described in 40 CFR 264.1082(b)((2), or 2) a tank used for biological treatment in accordance with 40 CFR 264.1082(c)(2)(iv) do not have to comply with 40 CFR 264/265.1084 (Standards: Tanks), but they do have to comply with the requirements for waste determinations (40 CFR 264/265.1083), and any applicable recordkeeping or reporting requirements. [40CFR 264/265.1089 and 1090].

\section{What new reporting requirements are contained in 40 CFR Part 264/265 Subpart CC?}

Each occurrence of a HazW being placed in a tank exempted from using air emission controls where the $\mathrm{HazW}$ does not meet 40 CFR 264/265.1082(c)(1) or (2) conditions, shall be reported to the EPA Regional Administrator. This may include an instance where HazW with an average volatile organic concentration equal to or greater than 100 ppm by weight at the point of waste origination has been placed in an exempted tank [40 CFR 264/265.1090(a)]. Additionally, owners/operators using a tank in accordance with the provisions of 40 CFR 264/265.1084(c) (fixed roof) shall report to the Regional Administrator each occurrence when HazW is managed in the tank in noncompliance with 40 CFR 264/265.1084(c)(1) through (c)(4). [40 CFR 264/265.1090(b)]

Owners/operators using a control device in accordance with 40 CFR 264/265.1087 shall submit a semi-annual written report if there have been any occurrences when a control device has been operated continuously for 24 hours or longer in noncompliance with the operating values of 40 CFR 264/265.1035(c)(4), or when a flare is operated with visible emissions as defined by 40 CFR 264/265.1033(d). [40 CFR 264/265.1090(c)]

Questions of policy or questions requiting policy

decisions will not be addressed in EH-413 Information Briefs unless that policy has already been established through appropriale documentation. Please refer any questions conceming the material covered in this Infomation Brief to Mark Petts, EH-413, (202) 586-2609. 